\title{
Inserturile și omisiunile în Catehismul calvinesc din 1648
}

\author{
Enikő Pál* \\ Facultatea de Științe Economice și Umaniste, Universitatea Sapientia, Piața Libertății 1, 530104 Miercurea Ciuc, România
}

\begin{tabular}{|c|c|}
\hline Despre articol & Rezumat \\
\hline Istoric: & Studiul de față este menit a contribui la cercetările asupra vechilor traduceri \\
\hline Primit 17 martie 2015 & românești, privite din perspectivă traductologică. În acest sens, finalitatea urmă- \\
\hline Acceptat 29 martie 2015 & rită o constituie aceea de a configura o tipologie a inserturilor și a omisiunilor \\
\hline Publicat 17 iulie 2015 & $\begin{array}{l}\text { observabile în traducerea românească a catehismului din } 1648 \text {, plecîndu-se de } \\
\text { la cauzele care le-au generat. Astfel, aplicînd metodele si instrumentarul proprii }\end{array}$ \\
\hline $\begin{array}{l}\text { Cuvinte-cheie: } \\
\text { text biblic } \\
\text { traducere } \\
\text { analiză comparată } \\
\text { filologie } \\
\text { diacronie }\end{array}$ & $\begin{array}{l}\text { analizei comparative, se urmăresc contextele în care traducerea românească pre- } \\
\text { zintă abateri de la una dintre cele două surse întrebuințate sau de ambele, precum } \\
\text { și considerentele care au putut orienta opțiunile traducătorului de a insera sau, } \\
\text { dimpotrivă, de a omite unități lingvistice de dimensiuni variate. În textul supus } \\
\text { analizei, statutul inserturilor și al omisiunilor variază de la caz la caz, însă, luate } \\
\text { în ansamblu, acestea pot fi grupate în două clase esențiale, reflectînd două nivele } \\
\text { de performanță diferite: nivelul creației, respectiv cel al imitației. }\end{array}$ \\
\hline
\end{tabular}

\section{Introducere. Sursele și concepția traducerii Catebismului din $\mathbf{1 6 4 8}$}

În literatura de specialitate, Catehismul calvinesc al lui Fogarasi István, tipărit la Alba Iulia în 1648, ocupă un loc destul de redus ${ }^{1}$. Cu toate că, în mod indiscutabil, acesta are o însemnătate mărginită, cel puțin în comparație cu celelalte texte contemporane, datorită și dimensiunilor sale reduse, respectiv destinației sale mai restrînse ${ }^{2}$, textul la care ne-am oprit prezintă interes sub mai multe aspecte. Dincolo de faptul că acesta se află într-o strînsă relație cu celelalte texte calvino-române din secolul al XVII-lea, cu implicații inclusiv culturale $^{3}$, o analiză oricît de superficială a limbii textului acestui catehism ne va dezvălui un material lingvistic extrem de bogat—sub aspect fonetic, morfologic și lexical. Or, acest aspect a fost insuficient valorificat pînă astăzi, deși un asemenea demers ar putea contribui la configurarea limbii române vechi din secolul al XVII-lea sau, în orice caz, a graiurilor ariei subdialectale sud-vest ardelenești căreia îi aparține textul vizat.

Dincolo însă de disponibilitatea și de potențialitatea sa dialectologică, catehismul din 1648 se remarcă și sub aspect traductologic. De altminteri, o serie de particularități lingvistice care caracterizează acest

*Adresă de corespondență: enikopaldr@gmail.com.

${ }^{1}$ Pentru prima dată, acesta intră în atenția cercetătorilor în urma unor fragmente excerptate din Crezul, publicate de Hasdeu (1879, p. 725-727), și de Gaster (1891, p. 124), unele fragmente din catehism regăsindu-se și în Nădejde (1886, p. 161, 379, 380). Apoi, textul este catalogat și în bibliografii vechi românești (BRV I, sub 53, p. 160-164) sau româno-ungurești (BRU, sub 167, p. 81) şi maghiare (RMK I, sub 803; RMK II, sub 683; Veress, 1910, p. 159; vezi și RMNy III, sub 2212). Pe lîngă aceste inventarieri, catehismul lui Fogarasi este amintit în treacăt și în volumele dedicate istoriei limbii, literaturii, și/sau bisericii românești, precum în: Philippide (1888, p. 51, 75); Sbiera (1897, p. 106); Marienescu (1902, p. 115); Iorga (1904, p. 144145; 1928, p. 302) etc. Valorificarea acestuia din perspectivă lingvistică se lasă, însă, așteptat. Un real progres, în acest sens, este făcut abia în 1942, cînd apare prima și, după știința noastră, singura ediție a acestui text, întocmită de Tamás Lajos. După această ediţie, catehismul din 1648 iarăși pare abandonat, cu excepția unor trimiteri din istorii ale limbii şi/sau ale literaturii românești. Dintre acestea, merită menționate, de pildă, unele observații asupra unor aspecte lingvistice în Gheție (1975, p. 305-309).

${ }^{2}$ Catehismul era propus pentru întrebuințări ,în aceste două locurĭ cu deosebire, în Lugoș și în Caransebeș pentru șcólele de religia creștinéscă și pentru întărirea în credință a tinerilor elevĭ de acolo", așa cum afirmă însuși autorul la p. 5 a Prefeței cărții (Tamás, 1942, p. 44, trad. rom. în BRV I, p. 163).

${ }^{3}$ Astfel, de pildă, textul a fost tipărit cu litere latine și cu ortografie maghiară, ceea ce nu este deloc inedit, ci reprezintă „expresia unitară a unei mișcări literare și religioase [calvine]” (Pantaleoni, 2007, p. 55), dezvoltată în zonele Banat-Hunedoara între secolele al XVI-lea și al XVII-lea. 
text decurge, direct sau indirect, tocmai din faptul că el este o traducere. Mai mult decît atît, alături de problemele generale care survin în cazul oricărui produs al unei asemenea îndeletniciri, textul prezintă și unele probleme specifice datorită (și) faptului că el reprezintă rezultatul traducerii directe a unei versiuni bilingve. Nu ne propunem să insistăm aici asupra diferențelor dintre o traducere efectuată pe baza a două sau a mai multe surse și o traducere care se edifică urmărind un singur text (vezi și Arvinte \& Gafton, 2007, p. 27). Dorim să menționăm, totuși, faptul că, în cazul unei asemenea situații, în care se găsește și traducerea lui Fogarasi, sporește nu numai polivalența demersului întreprins (a actului traducerii, atît la nivelul receptării/interpretării textului-sursă, cît și la nivelul producerii textului-țintă), ci și complexitatea textului produs.

Sursa traducerii Catehismului lui Fogarasi o constituie o versiune latino-maghiară a catehismului de la Heidelberg. Această versiune bilingvă a Catechismus Religionis Christianæ a cunoscut mai multe ediții, printre care în 1636, 1639, 1643, 1647, dar și ediții ulterioare. Textul lui Fogarasi se bazează, probabil, fie pe ediția din 1643, fie pe cea din 1647, eventual pe cea din 1639 (vezi și Tamás 1942, p. 11, 129). De altminteri, edițiile din 1639, 1643 și 1647—cea din urmă constituind o retipărire fidelă a edițiilor anterioare (cf. RMNY III, sub 2167, RMK II, sub 672, RMK I, sub 790) -sînt aproape identice, astfel încît stabilirea exactă a ediției-sursă a textului lui Fogarasi este greu de făcut ${ }^{4}$. Pentru stabilirea textului de bază latino-maghiar, se pot invoca două puncte de sprijin: unul formal, atît traducerea românească, cît și versiunea latino-maghiară conținînd 77 de întrebări și răspunsuri; și unul stilistic, textul lui Fogarasi prezentînd numeroase maghiarisme, inclusiv împrumuturi culte, preluate direct din sursă, precum și o serie de calcuri după maghiară.

Cum este și firesc, textul românesc nu reproduce, în mod fidel și integral, nici textul latin, nici pe cel maghiar, modalitățile de întrebuințare și de îmbinare a celor două surse fiind mult mai variate. Astfel, traducerea românească prezintă porțiuni care pot fi atribuite, cu certitudine, fie versiunii maghiare, fie celei latine, dar și segmente care arată o compilație a celor două modele sau o eliberare de ambele, secvența respectivă edificîndu-se, în mod independent de surse, prin contribuția personală a traducătorului care, pe alocuri, depășește chiar și atribuțiile unui traducător, în sensul strict al cuvîntului.

$\mathrm{Cu}$ toate soluțiile virtual oferite de existența celor două surse, luat în ansamblu, textul românesc se edifică prin contribuția inegală a celor două texte-sursă, modelul maghiar arătîndu-se a fi mult mai prezent în rezultatul traducerii decît cel latinesc. Faptul că Fogarasi întrebuințează preponderent sursa maghiară poate fi susținută prin numeroase „mărci ale traducerii” ${ }^{5}$, cu alte cuvinte, printr-o serie de indicii care

\footnotetext{
${ }^{4}$ Unele diferențe se constată la nivelul numerotării citărilor din textele biblice. Spre exemplu, sub 12/8, Fogarasi face trimitere la Gen. 2. v. 1, pe cînd, în edițiile latino-maghiare din 1639 și 1643, citarea este din Gen. 2. 17. La fel, sub 12/18, Fogarasi menționează Matt. 6, iar edițiile din 1639 și 1643 amintesc Matth. 6. 12. În mod asemănător, sub 28/16, textul românesc menționează doar Act. 2., pe cînd edițiile din 1639 și 1643 amintesc Act. 2. 39. Un alt caz avem sub 16/3, unde trimiterea se face la Act. 4. v. 13, spre deosebire de versiunile latină și maghiară a edițiilor din 1639 și 1643, în care se citează din Act. 4. 12. Asemănătoare este și situația sub 18/20, unde trimiterea se face la $\mathbf{L u c}$. 23. v. 13, pe cînd, în textele latinesc și unguresc din 1639 și 1643, citarea se face din $\mathbf{L u c}$. 23. v. 13. 14. O altă diferență se constată sub 29/12, unde Fogarasi notează Matt. 20. v. 26. 27. 1. Cor. 10. v. 16., iar versiunile latină și maghiară din edițiile din 1639 și 1643 înregistrează Matth. 26. v. 26. 27. 1. Cor. 10. 16. O altă inadvertență găsim sub 16/19, unde fragmentul pus în atenția cititorului este Rom. 8, pe cînd, în sursa latină din 1643, se notează Rom. 8. 34, iar, în cea maghiară, Rom. 8. 14. La fel, sub 22/18, Fogarasi menționează Matt. 16. v. 19, pe cînd versiunile latinească și maghiară din 1643 amintesc Matth. 16. 18. În mod asemănător, sub 39/7, Fogarasi notează Prov. 30. v. 9., iar versiunile latină și maghiară din edițiile din 1639 și 1643 înregistrează Prov. 30. v. 8. 9. (cea latină), respectiv Prov. 30. 8. 9. (cea maghiară). La fel, sub 39/15, textul românesc citează din Ephes. 4. v. 24., pe cînd edițiile latino-maghiare din 1639 și 1643 citează din $\boldsymbol{E p h}$. 4. 25. Tot astfel, sub 43/16, Fogarasi citează Psal. 143, iar edițiile latino-maghiare din 1639 și 1643 trimit la $\boldsymbol{P}$ sal. 143. 10. În mod asemănător, sub 45/4, textul românesc notează $P$ sal. 143, iar edițiile din 1639 și 1643 înregistrează Psal. 143. 10 (vers. lat.), respectiv Psalm. 143. 10 (vers. mgh.). Însă, în asemenea cazuri, este destul de greu a trage concluzii neechivoce, întrucît unele dintre aceste deosebiri s-ar putea datora, bunăoară, și neatenției traducătorului, eventual, unor greșeli de tipar, mai ales avîndu-se în vedere faptul că citările nu fac trimiteri la cu totul alte locuri, micile diferențe fiind observabile doar privind numerele versiunilor citate, uneori uşor confundabile, sau privind lipsa unor numere ce putea rezulta (și) în urma omiterii conștiente a autorului, urmărind, eventual, scopuri de economie. De aceea considerăm că acestea, singure, nu pot constitui o dovadă absolută a întrebuințării ediției din 1647.

${ }^{5}$ Asupra indiciilor care pot funcționa drept „mărci ale traducerii”, cu aplicație pe textul Paliei, vezi și în Arvinte \& Gafton
} 
arată, în mod indiscutabil, urmărirea textului maghiar, întrucît acele elemente ale textului românesc nu au corespondent în textul latin, dar redau exact ceea ce apare în textul maghiar. Printre aceste mărci ale traducerii figurează: împrumuturile culte preluate direct din sursa maghiară și calcurile maghiare care apar ca o replică imediată la textul de tradus, tiparele morfo-sintactice care redau modelul maghiar, unele nume proprii, unele citări biblice, precum și inserturile și omisiunile, cele din urmă constituind, în continuare, principala noastră preocupare.

\section{Statutul inserturilor și al omisiunilor în textul lui Fogarasi}

Urmărind pas cu pas traducerea românească, respectiv versiunea maghiară, pe de o parte, și cea latinească, pe de altă parte, întîlnim numeroase situații în care Fogarasi inserează în textul lui sau omite din acesta anumite cuvinte, sintagme sau segmente de dimensiuni mai reduse faţă de unul dintre textele-sursă întrebuințate sau de ambele. În mod firesc, funcționalitatea acestor inserturi și omisiuni se prezintă în mod diferit de la caz la caz. Astfel, prin inserturile și omisiunile independente de versiunile-sursă, de pildă, traducătorul român își atribuie, pe anumite porțiuni, roluri care depășesc actul traducerii, apropiindu-se de nivelul unui act de creație. Față de acestea, inserturile și omisiunile operate de Fogarasi care se regăsesc într-una dintre versiunile-sursă, dar lipsesc din cealaltă, funcționează ca mărci ale traducerii. În esență, deosebirea dintre cele două categorii de inserturi și omisiuni privește, într-un caz, asumarea, pe moment, a unor libertăți în ciuda constrîngerilor formale și de conținut, impuse de surse, iar, în celălalt caz, servilismul față de unul dintre modele.

\subsection{Inserturile și omisiunile independente de sursele întrebuințate}

În ansamblu, textul lui Fogarasi se edifică plasîndu-se între imitație și creație. La nivel microstructural, însă, și una și cealalta pot fi surprinse, uneori, în mod destul de evident. Situaţiile în care traducerea românească se plasează în sfera creației pot fi ilustrate, printre altele, de inserturile și omisiunile executate în mod independent atît de textul-sursă maghiar, cît și de cel latin.

\subsubsection{Inserturi independente de surse}

De regulă, inserturile au menirea de a oferi lămuriri cu privire la anumite sensuri întîlnite în textul de tradus, unele dintre acestea apărînd în contextul unor termeni de origine maghiară. $\mathrm{O}$ asemenea situație întîlnim în: „semeliuri sau obraze” (14/12-13) , cf. mgh. személyek, cf. lat. persone. În acest caz, împrumutul cult de origine maghiară semeliuri 'persoane', preluat direct din sursa maghiară (cf. mgh. személyek 'id.'), putea să-i fi părut lui Fogarasi mai puțin familiar publicului căruia îi era destinat catehismul, drept pentru care introduce pasajul lămuritor. Tot ca un insert cu rol explicativ funcționează și termenul subliniat în: „bătăi sau bintetluială” (12/2), cf. mgh. büntetések, cf. lat. poenis, de data aceasta, însă, introducerea tocmai a maghiarismului vine în ajutorul lămuririi unui sens posibil calchiat după maghiară, regăsit în bătaie 'pedeapsă (divină) ${ }^{7}$. Un calc după maghiară este explicat și în adaosul suplimentar în: „a ne ține sau ne ispăsi” (16/5-6), cf. mgh. megtartatnunk, cf. lat. servati. Aici termenul de origine slavă, introdus de Fogarasi, pare a servi la elucidarea sensului cu care se încarcă verbul $a(s e)$ ține 'a (se) mîntui', în urma calchierii mgh. megtart 'a ține'.

Introducerea unui cuvînt sau a unei sintagme în traducerea românească răspunde, pe de o parte, nevoii de a oferi lămuriri, clarificări pentru sensurile termenilor întrebuințați, datorîndu-se, probabil, unor considerente lingvistice, precum în exemplele arătate mai sus. Pe de altă parte, însă, există și situații în

(2007, p. 52-188).

${ }^{6}$ Citatele sînt redate arătîndu-se pagina/rîndul textului catehismului. În ediția lui Tamás (1942), paginile nu sînt segmentate în rînduri. Astfel, numerotarea rîndurilor ne aparţine.

${ }^{7}$ Este interesant faptul că Fogarasi nu întrebuințează nicăieri substantivul pedeapsă și nici verbul a pedepsi. Echivalentele acestora sînt maghiarismele bintetluială și a bintetlui, respectiv bătaie. Cu acest sens, cel din urmă se notează, în acelaşi context, și în catehismul din 1656: „a păți bătae și biciu” (Barițiu, 1879, p. 35). Cu înțelesul arătat, termenul bătaie are mai multe ocurențe în textul lui Fogarasi, printre care în: „nu va lăsa fără bătaie” (34/1-2), cf. mgh. büntetés, cf. lat. impunitum, corespunzînd pasajului: „nu va lăsa... necercatŭ” din celălalt catehism (Barițiu, 1879, p. 44). 
care introducerea unor termeni suplimentari, în contexte în care apar și sinonimele lor, nu se motivează din rațiuni strict lingvistice, cuvintele pe care le însoțesc fiind perfect funcționale și frecvent întîlnite în epocă, și, prin urmare, neimpunînd, în mod necesar, pasaje lămuritoare. Asemenea cazuri întîlnim în: „chemi au numești” (17/5), cf. mgh. nevezed, cf. lat. appellas; „vestiți sau pomeniţi” (30/4-5), cf. mgh. hirdessétek, cf. lat. annuntiate; „certare sau vrava a Bisericii Sfînte” (30/24), cf. mgh. fenyiték, cf. lat. disciplina; „să nu supere, sau nu dosădească” (39/3-4), cf. mgh. meg ne nyomoritsa, cf. lat. opprimat; „Inălția sau Măria a lu Dumnedzeu din cer” (41/22-23), cf. mgh. Istennek mennyei felsége, cf. lat. coelesti majestate Dei; „fericăciune sau lauda” (45/23), cf. mgh. dicsőség, cf. lat. gloria; „bintetluială de o vreme sau trupească" (12/3) (12/2-5), cf. mgh. ideig való büntetésekre, cf. lat. temporalibus poenis. În aceste situații, nu este exclus ca inserturile respective să reflecte (și) încercările autorului de a nuanța exprimarea, alternarea diverselor lexeme echivalente urmărind, deci, finalități inclusiv stilistice.

Traducerea românească înregistrează și inserturi care nu se datorează, în mod necesar, unor considerente strict lingvistice și nici nu urmăresc scopuri stilistice, ci reflectă, mai degrabă, opțiuni ale traducătorului. Spre exemplu, un termen negăsit în sursele latină și maghiară, introdus de Fogarasi, întîlnim în: „Trei sînt în cer... Tatăl, Fiul, sau cuvîntul, și Duhul Sfînt” (14/15-16), cf. mgh. „Hárman vagynak az égben... az Atya, az Ige, és a’ Szent Lélek”, cf. lat. „Tres sunt qui in cœlo... Pater, Verbum, et Spiritus Sanctus”. Tot așa, la sfîrșitul Crezului, Fogarasi introduce termenul amen 'amin' (13/24), lucru interesant din moment ce această interjecție nu apare nici în textul latin, nici în cel maghiar în segmentul respectiv.

Pe lîngă acestea, se găsesc și unele fragmente de texte ungurești și latinești, încorporate în traducerea românească, fără ca acestea să apară în versiunile-sursă. Astfel, formula latinească „Gloria Deo. Venia Reo”, cu care se încheie textul propriu-zis al catehismului (al celor 77 de întrebări și răspunsuri), este urmată de formula maghiară „Dicsőség Istennek. Bocsánat a' bűnösnek” (46/9-10). De asemenea, formulele de încheiere a traducerii lui Fogarasi sunt redate în limba maghiară: „Vége” (48/11), respectiv în limba latină: „Soli gratias tibi, o gratiose Deus” (48/12-13).

\subsubsection{Omisiuni independente de surse}

Există şi cazuri în care Fogarasi omite anumite cuvinte care se regăsesc atît în versiunea latinească, cît şi în cea maghiară. Un asemenea caz întîlnim în: „acel un Dumnedzeu de vecie” (14/13-14), cf. mgh. „amaz egy igaz örökké való Isten”, cf. lat. „unus ille verus et æternus Deus”. În mod asemănător, traducătorul omite un termen în: „El dă tutrora vieață și toate” (15/18-19), cf. mgh. „Ö ád mindeneknek életet és lehelletet és mindeneket”, cf. lat. „Ipse dat omnibus vitam, et halitum, et omnia”. Același fenomen se observă și în: „Cum după această vieați voi avea fericăciune deplină” (26/6-7), cf. mgh. „Hogy ez élet után tellyes és tökélletes boldogságom lészen”, cf. lat. „Quod post hanc vitam plena perfectaque beatitudine potiar”. La fel, Fogarasi omite o sintagmă regăsită în textele-sursă în: „De la răsăritul soarelui lăudat fie Numele Domnului” (42/11-12), cf. mgh. „Napkelettől fogván mind nyugatiglan dicséretes légyen az Vrnak neve”, cf. lat. „Ab ortu solis usque ad occasum eius sit laudatum nomen Iehova”. Este însă greu a spune dacă asemenea omisiuni reprezintă asumarea deliberată a unor libertăți sau ele se datorează, eventual, neatenției.

În unele cazuri, însă, omiterea unei porțiuni care se regăsește în sursele latină și maghiară face ca textul românesc să devină destul de obscur, precum în: „Că pre acela care păcat nu știa prentru noi să fim în el dereptate a lu Dumnedzeu” (23/17-19), cf. lat. „eum enim, qui non noverat peccatum, propter nos peccatum fecit, ut nos essemus in eo justitia Dei”, cf. mgh. „Mert azt a’ ki bünt nem tudott vala, mi érettünk bünné tövé, hogy mi lennénk Isten igazságává ő benne”.

\subsection{Inserturi și omisiuni ca mărci ale traducerii}

Deși textul latin este și el prezent în produsul final al traducerii românești, există numeroase situaţii în care textul românesc urmărește, fie la nivel formal, fie sub aspectul conținutului, versiunea maghiară. Printre indiciile de identificare a sursei maghiare figurează (și) inserturile și omisiunile observabile în textul românesc, pe de o parte, și în textul-sursă maghiar, pe de altă parte, nefiind regăsite, însă, în versiunea latinească. În mod firesc, faptul că textul românesc se supune, exclusiv sau preponderent, influenței sursei 
maghiare se poate susține cu certitudine doar în și pentru segmentul de traducere care înregistrează aceste indicii.

\subsubsection{Tipologia inserturilor efectuate după sursa maghiară}

În mod firesc, calitatea de insert al unor cuvinte, sintagme etc. regăsite în textul românesc, pe de o parte, și în sursa maghiară, pe de altă parte, se datorează diferențelor observabile între cele două versiuni-sursă (maghiară și latinească) ale traducerii. Inserturile românești care redau întocmai modelul maghiar, ele lipsind din cel latin, îndeplinesc diverse funcții la nivelul construcției și al structurării textului românesc. Astfel, în cadrul inserturilor, putem distinge unele subclase, precum: inserturi afective, discursive, sintactice, respectiv lexicale-explicative.

\subsubsection{Inserturi afective}

În categoria inserturilor afective putem include acele secvențe care au o funcție mai degrabă fatică și un rol stilistic, fiind regăsite în interogații retorice, în formulări cvasi-hiperbolice sau în construcții iterative care urmăresc tiparul de expresie și modelul de construcție a discursului oferit de sursa maghiară.

Un asemenea exemplu îl constituie inserarea adverbului interogativ oare, redînd mgh. vallyon cu același sens și funcție, în: „Oare de unde izvorăște aceea credință ?” (26/14-15), cf. mgh. „Honnan származik vallyon az a hit?”, cf. lat. „Unde hace fides proficiscitur?”; sau în: „Oare de unde este năravului omenesc atare mare sdrobitură?” (11/6-7), cf. mgh. „Honnan vagyon vallyon az emberi természetnek ilyen nagy romlotsága?”, cf. lat. „Unde existit hæc naturæ humanæ pravitas?”. În secvența din urmă, prezența sursei maghiare poate fi surprinsă și în sintagma: „atare mare sdrobitură” care corespunde formulării maghiare „ilyen nagy romlotsága”, ambele încorporînd un determinant menit să accentueze, să intensifice amploarea fenomenului descris. Față de acestea, textul latin nu înregistrează nici un termen cu rol intensificator, situația descrisă fiind redată doar prin substantivul „pravitas”.

Un rol intensificator au și expresiile care redau modelul maghiar în: „Numai singur prin credinţa a lu Isus Hristos, în atîta, cum fără de toată destoinicia a mea, curat numai din meserere a lu Dumnedzeu mi se destoinicește mie făcătura de destul cu plin” (23/22-24/2), cf. mgh. „Csak egyedül a' Jesus Christusban való hit által, el annyira, hogy minden én érdemem nélkül, csupán csak az Istennek irgalmasságából tulajdonítassék és ajándékoztassék énnékem.... tökélletes elégtétele”, cf. lat. „Sola fide in Jesum Christum, adeo ut sine ullo meo merito, ex sacra Dei misericordia, perfecta satisfactio... mihi imputetur ac donetur".

Cu efecte stilistice se utilizează și avertismentul formulat prin construcția iterativă în: „Din poamele pomului știutului binelui și al răului să nu mănînci că oare în ce zi vei mînca cu moartea morției vei muri" (12/8-10), cf. mgh. „Az jónak és gonosznak tudásának fájának gyümölcsében ne egyél, mert valamely napon abban ejéndel halálnak halálával halsz meg”, cf. lat. „De fructu arboris scientiæ boni et mali, de isto ne comedas, nam in quo die comederis de eo, utique moriturus es”. Cu toate că expresia aparține tradiției biblice, ea fiind de origine ebraică, preluată, apoi, și în celelalte limbi în care s-a tradus Biblia (cf. și lat. morte morieris, morte morietur), prezența acesteia în textul românesc acolo unde este prezentă în modelul unguresc, lipsind, însă, din versiunea latină, se datorează, probabil, influenței textului-sursă maghiar.

Tot o funcție mai degrabă stilistică au și construcțiile iterative construite după modelul maghiar, în: „Nu nici dintr-o parte ce mai tare din zi în zi datoriile noastre mărindu-le mărim” (12/15-17), cf. mgh. „Semmi részből nem: sőt inkább naprol napra adosságunkat öregbitten öregbittyük”, cf. lat. „Nulla ex parte: quin etiam debitum, in singulos dies, augemus".

Nu este exclus nici ca pasajul care redă rugăciunea Tatăl nostru să fi urmărit modelul maghiar, întrucît traducerea românească înregistrează construcția iterativă regăsită și în versiunea maghiară a acestui text, în: „Că-i a ta împărăția, puterea, și lauda pînă-n vecie, veacului” (41/5-6); sau în: "pînă în vecie de veac" (45/11), cf. mgh. „Mert tiéd az ország, a' hatalom, és a' dicsőség mindörökkön örökkê”, cf. lat. "Quia tuum est regnum, et potentia, et gloria in secula" ${ }^{8}$.

\footnotetext{
${ }^{8}$ De altminteri, construcția iterativă se întîlnește și în alte cîteva traduceri românești vechi ale rugăciunii. Astfel, în secolul
} 


\subsubsection{Elemente cu rol discursiv}

O altă categorie de elemente inserate în textul lui Fogarasi care nu se găsește în sursa latinească, dar redau segmente ungurești, o constituie elementele care asigură și/sau întăresc coerența textului la nivel discursiv, fără implicații sintactice propriu-zise. Elementele de acest gen sînt reprezentate, în marea lor majoritate, de clasa adverbelor, dar găsim, printre ele, și unele interjecții și adjective.

Un asemenea insert discursiv întîlnim în: „în atîta cum $\boldsymbol{a} \boldsymbol{a} \boldsymbol{u}$ toți în păcat ne prindem și ne naștem” (11/8-10), cf. mgh. „ugy hogy immár mindnyájan a' bünben fogantassunk és születtessünk”, cf. lat. „ita ut omnes in peccato concipiamur et nascamur".

O situație asemănătoare o reprezintă introducerea interjecției în secvența: „Iacă în alnicie m-am prins și muma mea în păcat m-a incălzitu-mă în sgăul său” (11/12-14), cf. mgh. „Ímé én álnokságban fogantattam, és az én anyám bűnben melegített engemet az ő méhében”, cf. lat. „Enim iniquitate formatus sum, et in peccato fovit me mater mea”. De altminteri, segmentul îi poate fi atribuit sursei maghiare și datorită împrumutului de origine maghiară alnicie (cf. mgh. álnokság, cf. lat. iniquitate), calcului după maghiară a (se) prinde (în...) 'a concepe, a zămisli' (cf. mgh. fogantat < fog-ni 'a prinde', cf. lat. formatus sum) și prezenței lexemului zgău (cf. mgh. méh 'id.'), care nu are corespondent în textul latin.

Textul lui Fogarasi înregistrează, cu numeroase ocazii, adverbul încă, acesta coresponzîndu-i adverbului is 'de asemenea, și, încă' din versiunea maghiară, acestea neavînd, însă, echivalente în versiunea latinească. Astfel, el se întîlnește în: „Cum el în toată vremea vieții lui încă, ce mai tare în vremea morții au pățit-o mînia a lu Dumnedzeu prentru păcatele noastre” (18/6-9), cf. mgh. „Hogy ő tellyes életének idejében is ugyan, de föképpen halálakor, az Istennek a' mi bűneinkért való haragját meg szenyvedte”, cf. lat. „Eum toto quidem vitæ tempore, præcipue vero in eius extremo, iram Dei adversus peccata nostra sustinuisse", unde și formularea ce mai tare redă expresia mgh. de fóképpen.

Același insert adverbial se găsește și în: „Căce pui și aceasta încă lîngă aceea” (20/1), cf. mgh. „Miért teszed ezt is hozzá", cf. lat. „Cur additur”; „Că ce se pune aceasta încă lîngă aceea” (21/3), cf. mgh. „Miért tétetik ez is hozzá”, cf. lat. „Cur additur”.

În mod asemănător, acesta se întîlnește în: „Să toate le-ați face încăa, carele vouă-s porîncite încăşi aceea dziceți” (25/13-15), cf. mgh. „Ha mindeneket meg cselekedtétek $\boldsymbol{i s}$, a' mellyek nektek parancsoltattanak, még is azt mondgyátok”, cf. lat. „Cum feceritis omnia quæ præcepta sunt vobis, dicite”. La fel, adverbul apare ca un insert în: „Adevăr zic vouă cum orice veți lega pre pămînt îi vor fi legate în cer încă, și orice veți dezlega pre pămînt dezlegate vor fi și în cer încă” (31/4-7), cf. mgh. „Bizony mondom ti néktek: Hogy valamiket meg köténdetek e' földön, meg lesznek az égben is köttetve, és valamiket meg oldozándotok e' földön, meg lesznek oldattatva az égben is”, cf. lat. „Amen dico vobis: Quæcunque ligaveritis in terra, erunt ligata in cœlo, et quæcunque solveritis in terra, erunt soluta in cœlo", unde sursa maghiară pare să-şi fi exercitat influența și asupra selecției prepoziției din sintagma: „pre pămînt”, cf. mgh. „földön”, cf. lat. „in terra”.

Insertul adverbial încă cunoaște și alte ocurențe, precum în: „Cum noi cu viața necertătoare a noastră pre alții încă să dobîndim lu Hristos” (31/20-22), cf. mgh. „hogy a’ mi feddhetetlen életünkel egyebeket is a' Christusnak meg nyerjünk”, cf. lat. „ut vitæ nostræ integritate alios Christo lucrifaciamus”; „Să

al XVI-lea, ea este înregistrată în Tatăl nostru al lui Luca Stroici (1593): „în veczij vecilor” (Gaster, 1891, p. 39), respectiv întrun fragment de text din Codicele Todorescu: „di veci-/e vecului” și „,ve-/cie vécu[lu]i” (Drăganu, 1914, p. 229). De asemenea, formularea se regăsește și în catehismul calvinesc din 1656: „véciĭ de vécŭ” (Barițiu, 1879, p. 48, 49). În cazul textului din urmă, nu este exclus ca această construcție să i se datoreze—asemenea textului lui Fogarasi-influenței sursei maghiare, din moment ce catehismul din 1656 pare să fi avut la bază aceeași versiune latino-maghiară a catehismului ca și cel dintîi (vezi și Drăganu, 1922, p. 164; Juhász, 1940, p. 192; Tamás, 1942, p. 10-15, 129, 131). Însă, nu este exclus nici ca asemenea formule să reflecte, eventual, o anumită versiune, cît de cît fixată sau „canonizată”, proprie cultului calvinesc, cu alte cuvinte o tradiție proprie versiunilor calvine ale acestei rugăciuni. Pentru diferitele versiuni românești ale rugăciunii Tatălnostru vezi și Niculescu (2006-2007, îndeosebi p. 48-72).

${ }^{9}$ De altminteri, acest segment cuprinde și un calc după maghiară: necertătoare 'neprihănit', cf. mgh. feddhetetlen (megfedd-ni 'a certa' + -etlen 'sufix negativ'), cf. lat. integritate. 
cerem mila încă a Duhului Sfînt” (40/8), cf. mgh. „a' Szent Léleknek kegyelmét is kérjük”, cf. lat. „gratiam Spiritus Sancti imploremus”; „Unde den toate nevoile numai din meserere a lu Dumnedzeu prentru Hristos ne-au slobozitu-ne, căce dară trebuiește încă a face bine?” (31/12-15), cf. mgh. „Holott minden nyavalyás voltunkbol csak az Istennek irgalmasságával a' Christusért szabadíttattunk légyen meg, miért kell tehát mégis jót cselekednünk?”, cf. lat. „Cum ab omnibus miseriis sola Dei misericordia, propter Christum liberati fimus, quid est, cur bona opera facimus?”; Să iară nu le veți ierta oamenilor păcatele lor, nici Tatăl vostru încă den cer nu le va ierta vouă greșelele voastre” (44/14-17), cf. mgh. „Ha pediglen ti meg nem bocsátandgyátok az embereknek az ő büneiket, a' ti mennyei Atyátok is nem fogja meg bocsátani tinektek a' ti vétkeiteket”, cf. lat. „Si autem non dimiseritis hominibus peccata eorum, nec dimittet vobis pater vester peccata vestra".

Un alt insert adverbial întîlnim în: „Domnul omoară și iarășite învie, jos pînă la păcură aruncă, și iarăşite scoate” (20/12-14), cf. mgh. „Az Vr meg öl, és ismét meg elevenít, a' pokolig alá vet és ismét fel hoz”, cf. lat. „Dominus deducit in inferno, et reducit”, unde traducerea românească urmărește și tiparul maghiar cu prefix verbal alá 'jos' vet 'aruncă.

Un alt adverb inserat, care redă sursa maghiară, găsim în: „că dreptăției a lu Dumnedzeu prentru păcatele noastre nici într-un chip aimintrilea destul n-are fi putut face” (19/9-12), cf. mgh. „mert az Isten igazságának semmiképpen a’ mi bűneinkért különben eleget nem tehetett volna”, cf. lat. „quod justitiæ Dei nullo alio pacto pro nobis peccatis potuit satisfieri”. De altminteri, segmentul acesta poartă și alte urme ale sursei maghiare, precum: expresia nici intr-un chip, cf. mgh. semmiképpen, cf. lat. nullo alio pacto, sau calcul după maghiară a face destul 'a satisface', cf. mgh. eleget 'destul' tenni 'a face'.

Tot ca un insert funcționează și adverbul în: „Acele ce cu credința dereaptă vom cere de la el cu nemica mai nu va tăgădui de noi” (41/12-14), cf. mgh. „azokat a’ mellyeket igaz hittel ő tőle kérünk semmivel inkább meg nem tagadja tölünk”, cf. lat. „quæ vera fide ab eo petimus, nobis multo minus negare”.

Un alt insert de natură discursivă îl reprezintă adjectivul subliniat în: „Nu numai vreo atare cunoscătură” (24/15), cf. mgh. „Nem csak valami olly isméret”, cf. lat. „Est non tantum notitia”; „Cu atare adaus făgădaș” (29/2-3), cf. „illyen hozzá adatott igérettel”, cf. „addita promissione”.

\subsubsection{Inserturi sintactico-frastice: conectori}

O subclasă aparte o constituie conectorii inserați în traducerea românească, acolo unde textul latinesc nu înregistrează nici un element de acest fel, avînd, însă, corespondent în sursa maghiară. De altminteri, şi aceste elemente se întrebuințează preponderent cu rol discursiv, delimitarea lor de clasa anterioară s-a făcut, însă, în virtutea faptului că, spre deosebire de primele, acestea marchează și diverse tipuri de relații sintactice (de coordonare sau de subordonare) la nivelul propoziției sau al frazei. Aici se pot menționa conjuncțiile, adverbele și pronumele relative, întrebuințate uneori chiar cu valoarea morfosintactică a corespondenților lor ungurești, precum și unele locuțiuni prepoziționale (sau adverbiale).

Astfel, de pildă, conjuncția adversativă iară corespunde, de obicei, lat. autem și mgh. pedig, precum în: „A doua iară asemenea este către această” (10/22-23), cf. mgh. „A második pedig hasonlatos ehhez”, cf. lat „Secundum autem simile est huic”. Însă, există și cazuri, în care, în textul latin, nu se notează nici un conector, iară redînd mgh. pedig, precum în: „Care va crede și se va boteza ispăsi-se va, care iară nu va crede păgubi-se va” (28/7-9), cf. mgh. „A' ki hiend és meg keresztelkedéndik üdvözül, a' ki pedig nem hiend, el kárhozik”, cf. lat. „Qui crediderit, et baptizatus fuerit, servabitur, Qui vero non crediderit, condemnabitur”; „A doua tablă iară cu șase porunci aceea învață” (35/19-20), cf. mgh. „A' második [tábla] pedig hat parancsolatokkal azt [adja előnkben]”, cf. lat. „posterior [tabula], sex præceptis, quæ officia..... În alt loc, textul latinesc întrebuințează conjuncția copulativă și nu cea adversativă, așa cum o fac textele românesc și maghiar, în: „Sfînt Paul încă numește pîinea trupul a lu Hristos, păharul iară chiuzluitura a sîngelui lui cu noi” (29/9-12), cf. mgh. „Szent Pál Apostol is a’ kenyeret Christus testének, a’ pohárt pedig az ő vérének velünk való közöltetésének nevezi”, cf. lat. „Apostolus Paulus panem apellat communionem corporis Christi, et poculum communionem sanguinis eius".

Un alt conector care redă modelul maghiar este derept însă care îi corespunde, formal și funcțional, 
mgh. mivel azért, în: „Cu cît derept însă destoinici sîntem spre bătăi sau bintetluială de o vreme sau trupească și spre bintetluială de vecie dară este vreo cale prin care cu Dumnedzeu să ne putem împăca?” (12/2-5), cf. mgh. „Mivel azért mind ideig s mind penig örökké való büntetésekre méltók vagyunk, vagyoné tehát valami út az mellyen az Istennel meg békéltessünk?”, cf. lat. „Quoniam igitur temporalibus et æternis pœnis obnoxii sumus, estne via, qua Deo reconciliemur ?”, unde se observă și inserția lui dară, cf. mgh. tehát. Același conector se prezintă ca un insert, redînd, de data aceasta, un alt corespondent unguresc, și în: „Derept însă acela încă ce va naşte din tine e Sfînt” (17/22 - 18/1-2), cf. mgh. „Annakokáért az is a' mi te belöled születik a' Szent”, cf. lat. „propterea etiam, quod nascetur ex te Sanctum”; „Derept însă uluim în chip de adevăr, cum omul el se îndereptă” (24/10-11), cf. „Annakokáért ezt állattyuk bizonyosképpen, hogy az ember meg igazittatik”, cf. lat. „Colligimus igitur fide justificari hominem”.

Alte situații sînt reprezentate de expresiile și locuțiunile în care intră termenul chip și care redau construcțiile ungurești formal echivalente. Astfel, nici într-un chip 'nicidecum' se înregistrează în: „Nici întrun chip: că din nărav sînt plecat spre urăciunea lu Dumnedzeu” (11/2-3), cf. mgh. semmiképen, cf. lat. minime; „Nici într-un chip nu-l va lăsa” (11/16), cf. mgh. Semmiképpen nem, cf. lat. Nequaquam; „nici intr-un chip aimintrilea destul n-are fi putut face" (19/11-12), cf. mgh. semmiképpen, cf. lat. nullo alio pacto. Expresia în ce chip 'cum, în ce fel' se notează în: „,̂n ce chip înțelegi aceasta...?” (20/21), cf. mgh. Miképpen, cf. lat. Quomodo ${ }^{10}$; „In ce chip trebuiește nouă pre noi să ne purtăm către Dumnedzeu?” (35/17-18), cf. mgh. „miképpen kellessék minékünk magunkat az Istenhez viselnünk”, cf. lat. „quo pacto nos erga Deum geramus”; „In ce chip trebuiește a cere mila a Duhului Sfînt?” (40/16-17), cf. mgh. „Miképpen kell a' Sz. Léleknek kegyelmét... kérnünk?”, cf. lat. „Quomodo gratiam Spiritus Sancti... debemus petere?”; ,în ce chip îngerii fac în cer” (43/11-12), cf. mgh. „a' miképpen az Angyalok az égben cselekszenek”, cf. lat. "quemadmodum faciunt Angeli in cœlo”. Tot cu o echivalență formală avem de-a face în cazul expresiei subliniate în: "Și în acest chip cea Sîmbătă de vecie în această viaţă s-o încep" (37/910), cf. mgh. „és ekképpen amaz örökké való Szombathot ebben az életben el kezdjem”, cf. lat. „atq. Ita sempiternum Sabbathum in hæc vita exordiar".

Un alt conector care redă modelul maghiar se înregistrează în: „Prentru ce ocă se chiamă Hristos Fiul unul născut a lui Dumnedzeu?” (16/23-24), cf. mgh. Miokért, cf. lat. Quam ob causa; „Prentru ce ocă chemi au numești pre Hristos Domnul nostru?" (17/5-6), cf. mgh. Miokért, cf. lat. Qua de causa; „Prentru ce ocă au murit Hristos?” (19/8), cf. mgh. Miokért, cf. lat. Qua de causa; consemnat și în varianta prentru ceastă ocă (19/9), cf. mgh. ezokáért, cf. lat. propterea.

Trebuie însă remarcat și faptul că nu în toate cazurile întrebuinţarea acestor conectori apare, în mod necesar, ca o replică imediată la sursa maghiară. Se pot invoca și alte considerente pentru apariția lor în textul lui Fogarasi, cel puțin teoretic. Astfel, pe de o parte, unii dintre acești conectori pot reflecta o tradiție premergătoare, aceștia caracterizînd, în general, textele calvino-românești cu care autorul putea fi familiar. Pe de altă parte, deprinderea cu anumite construcții sintactice „străine” se poate menține în stare latentă și pe durata actului traducerii propriu-zise, astfel încît anumite formulări îi puteau rămîne întipărite în mintea traducătorului pe care, apoi, le putea întrebuința, eventual, și fără ca segmentul maghiar să exercite o presiune inevitabilă asupra opțiunii traducătorului. Astfel, cu certitudine deplină se poate susține doar faptul că aceste elemente coincid cu corespondenții lor formali din textul maghiar, cu sau fără corespondenți semantici în versiunea latinească.

Un grad mai ridicat de certitudine oferă acei conectori care preiau, uneori, și valorile morfosintactice ale corespondenților lor ungurești. Un asemenea exemplu îl constituie adverbul relativ cum, care adesea corespunde mgh. hogy, fiind întrebuințat (și) cu valențele celui din urmă. Astfel, în maghiară conjuncția hogy are valoare neutră, ea nefiind specializată pentru un anumit tipar de întrebuințare, cunoscînd aproape nelimitate posibilități de contextualizare, putînd introduce aproape orice fel de subordonată. Spre deo-

\footnotetext{
${ }^{10}$ În alt loc, formularea redă alte corespondente din textele-sursă: „,̂n ce chip se împart aceste porînci ?” (35/14), cf. mgh. mimódon, cf. lat. quomodo. Cu același înțeles se întrebuințează și expresia cu ce mod 'cum, în ce fel' în: „cu ce mod să mă slobod eu din toată nevoia mea” (9/23-24), cf. mgh. mimódon, cf. lat. quo pacto, aceasta fiind înregistrată și în contexte (vezi în 23/20) în care apare și echivalentul lat. quomodo.
} 
sebire de aceasta, în română, adverbul relativ cum introduce, în mod prototipic, subordonate modale ${ }^{11}$. În mod firesc, adverbul românesc, la rîndul lui, poate introduce și alte tipuri de subordonate, însă, în unele cazuri, acesta corespunde, în mod indiscutabil, conjuncției hogy, mai ales atunci cînd textul latin nu consemnează nici un conector. Astfel, cum redă mgh. hogy în contextele în care acesta se întrebuințează cu sensul 'că, introducînd subordonate completive directe, precum în: „S,tim cum acelora cari îndrăgesc pe Dumnezeu toate sunt spre bine” (9/17-18), cf. mgh. „Tudgyuk hogy azoknak akik az Istent szeretik, mindenek javukra vagynak”, cf. lat. „Novimus, iis qui diligunt Deum, omnia simul adjumento esse ad bonum”; „Cred cum Tatăl de vecie a Domnului nostru a lu Isus Hristos... mie încă îmi este Tatăl și Dumnedzeu” (15/1-5), cf. mgh. „Hiszem hogy a’ mi Urunk Jesus Christusnak örökké való Attya... énnékem is Istenem és Atyám légyen”, cf. lat. „Credo æternum Patrem Domini nostri Jesu Christi... meum quoq, Deum et Patrem meum esse”; "Să știe cum eu sînt Domnul carele pre ei sfințesc” (37/13-14), cf. mgh. „meg tudnák, bogy én vagyok az Vr, a' ki őket megszentelem”, cf. lat. „scirent, quod ego Dominus sanctificans eos”; „Un lucru fac cum acele ce mi-s după dos să le uit” (42/22-23), cf. mgh. „Egy dolgot cselekszem hogy azokat a' mellyek a hátam megett vagynak el felejtvén”, cf. lat. „Unum ago, ea quidem, quæ a tergo sunt, obliviscens". În alte cazuri, cum se întrebuințează cu sensul 'ca să, introducînd finale, asemenea conjuncției mgh. hogy, precum în: „Hristos odată s-au jertfăluit cum păcatele a mulți să le ia” (16/18-19), cf. mgh. „Christus egyszer megaldoztatott, bogy sokaknak büneiket elvenné”, cf. lat. "Chritus semel oblatus est, ut multorum peccata tolleret”; „Priveghiați și vă rugați cum în ispită să nu cădeți” (45/6-7), cf. mgh. „Vigyázzatok és imádkozzatok, bogy kisértésben ne essetek”, cf. lat. „Vigilate et orate, ne intrœatis in tentationem" ${ }^{12}$.

Pronumele relativ $c e$ este întrebuințat (și) cu sensul 'dar, însă', asemenea conjuncției ungurești de 'dar, însă, urmînd, deci, modelul maghiar, mai ales în cazul în care versiunea latinească nu înregistrează nici un conector, precum în: „Au vom via au vom muri ce a Domnului suntem” (9/14-15), cf. mgh. „Akár éllyünk akár hallyunk, $\boldsymbol{d} \boldsymbol{e}$ az Vréi vagyunk”, cf. lat. „Sive vivimus, sive morimus, Domini sumus”. Relativul ce se notează, cu un alt corespondent semantic maghiar, dar cu acelaşi sens adversativ, și în: „Pre Dumnedzeu nicicînd nime n-au văzut, $\boldsymbol{c e}$ acel Fiul unul născut care este în sînul Tatălui lui, el ne-au povestuit nouă” (16/15-17), cf. mgh. „Az Istent soha senki nem látta hanem amaz egygyetlen egy szülött Fia, a' ki az ő Attyának kebelében vagyon, beszéllette meg mi nékünk”, cf. lat. „Deum nemo vidit unquam: unigenitus ille filius, qui est in sinu Patris, ille nobis exposuit”. Pe de altă parte, segmentul pare a urmări modelul maghiar și în topică (vezi „nicicînd nime n-au văzut”, cf. mgh. „soha senki nem látta”), respectiv în formularea „Fiul unul născut” care redă perfect construcția mgh. „egygyetlen egy szülött Fia”.

Conjuncția $c \breve{a}$ este folosită cu înțelesul 'deoarece, fiindcă', în contextul în care versiunea maghiară înregistrează conectorul echivalent, spre deosebire de cea latinească, în care nu se notează nici un conector, precum în: „Nici într-un chip: că din nărav plecat sunt spre urăciunea lui Dumnezeu” (11/2-3), cf. mgh. „Semmiképpen nem: mert természet szerént hajlandó vagyok az Istennek... gyülölésére”, cf. lat. „Minime. Natura enim propensus sum ad odium Dei”. O situație asemănătoare întîlnim în: „Pre trei părți: că parte de prima este de pre Tatăl Dumnedzeu” (14/3-4), cf. mgh. „Három részekre: Mert az első vagyon az Atya Istenroll”, cf. lat. „In tres partes. Prima est de Deo Patre”.

Prin urmare, deși fragmentele românești corespund și celor din versiunea latinească, prezența conectorilor semnalați în traducerea românească, cu echivalente în versiunea maghiară, dar lipsind din cea latinească, poate servi drept indiciu al întrebuințării textului-sursă maghiar, eventual al compilaţiei celor

\footnotetext{
${ }^{11} \mathrm{O}$ asemenea situație avem în: „și acum încă așa mă ține, cum toate să-mi slujească spre ispăsenie-mi” (9/11-13), cf. mgh. „és még most is ugy tart, hogy mindenek az én idvösségemre szolgállyanak”, cf. lat. „meque ita conservat, ut omnia saluti meæ servire oporteat”, cu toate că, în acest caz, formularea are și valențele unei consecutive . În segmentul citat, urmărirea modelului maghiar poate fi susținută, însă, și prin insertul încă, cf. mgh. még, respectiv prin construcția sintactică „să-mi slujească spre ispăsenie-mi”, cf. mgh. „az én idvösségemre szolgállyanak”.

${ }^{12}$ Vezi și alte contexte de echivalare a lui cum cu mgh. hogy, în: „Aceasta; cum cu trup cu suflet au voi via au voi muri, eu sunt a Domnului vernic al mieu” (9/6-8), cf. mgh. „Ez, hogy mind testestől lelkestől, akár élyek, akar hallyak, az én hűséges Uramnak [...] tulajdona vagyok”, cf. lat. „Quod animo pariter et corpore, sive vivam, sive moriar, fidissimi Domini [...] sum proprius”; „Cum cu Numele Sfinției sale...” (36), cf. „Hogy az ő Szentséges nevével..., cf. „Ut Sacrosancto ipsus nomine...”.
} 
două surse.

\subsubsection{Inserturi lexicale}

Numeroase sînt și situațiile în care prezența unui element lexical, perfect autonom din punct de vedere semantico-funcțional, în traducerea românească, cu un echivalent semantic în sursa maghiară, servește drept indiciu al urmăririi, pe porțiunea respectivă, a versiunii maghiare, cu atît mai mult cu cît sursa latinească nu prezintă nici un lexem corespunzător, formularea, în aceasta din urmă, fiind mai concisă. De regulă, aceste inserturi de cuvinte și/sau sintagme față de textul latinesc funcționează drept pasaje lămuritoare sau note explicative, reflectînd, în același timp, și strădania traducătorului către precizie.

Asemenea inserturi lexematice întîlnim, de pildă, cu ocazia enumerării cărților sacre: „Despre ceremoniile a Levițenilor” (7/21-8/1), cf. mgh. „a' levitai Ceremoniákrol”, cf. lat. „Leviteus”; „Despre băgătura de samă a dihaniei” (8/2-3), cf. mgh. „a’ népnek megszámláltatásárol”, cf. lat. „Numeri”; „Despre duplecătură a legiei” (8/4-5), cf. mgh. „az Törvénynek meg kettőztetéséről”, cf. lat. „Deuteronomium”.

Un alt insert datorat urmăririi modelului de construcție a mesajului oferit de sursa maghiară avem în: „Cîte lucruri trebuiește ție să știi cum cu această veselitură viind, fericată să fie vieața ta și moartea ta?” (9/19-21), cf. mgh. „Hány dolgot kell tenéked tudnod, hogy ez vigasztalással élvén, boldogul lehessen életed és halálod?”, cf. lat. „Quot sunt tibi scitu necessariant ista consolatione fruens, beate vivas et moriaris?" 13 .

Versiunea latinească este mult mai concisă față de cea maghiară care pare a fi urmărită în: „Ne învață pre noi pre aceea Domnul Hristos într-o summă la Sfint [ul] Mathe [Matei] în douăzeci și două de părți”" (10/15-17), cf. mgh. „Megtanít minket arra Christus Urunk egy summában Sz. Mathénak 22 részében”, cf. lat. „Id nos docet Christus Summatim Matth. 22”.

Un alt insert se observă în: „De lipsă este, cum au noi îns să facem destul, au prin altul” (12/6-7), cf. mgh. „Szükség, hogy vagy mi magunk tegyünk eleget, vagy más által”, cf. lat. „Necesse est vel per nos, vel per alium satisfaciamus".

Alte inserturi lexematice întîlnim în: „Mai mult nu sînteți slugi ce feți” (15/7-8), cf. mgh. „Nem vagytok többé szolgák, hanem fiak”, cf. lat. „Non estis servi, sed filii”; „Ce crezi cînd aceea dzici...” (17/12, 18/4), cf. mgh. „Mit hiszesz mikor azt mondod...”, cf. lat. Quid credis cum dicis...”; „Atunci va zice Craiul acelora cari de mîna dreaptă vor fi” (21/16-17), cf. mgh. „Akkoron modngya a' Király azoknak a' kik job keze felől lesznek”, cf. lat. „Tum dicet Rex iis, qui ad dextra ipsius erunt”; „Cum toți vernicii îs chiuz și partnici a lu Hristos” (23/1-2), cf. mgh. „Hogy minden hivek a' Christusnak ... közösi és részesi légyenek”, cf. lat. Quod singuli credentes Christi... communionem habeant”; „Toatele dereptățile noastre îs ca cîrpă necurată a muierii” (25/6-7), cf. mgh. „Minden mi igazságink ollyanok mint a' havas aszony állatnak tisztátalan ruhája”, cf. lat. „Omnes nostræ justitiæ sicut panniculus abjectissimus”; „Care (Hristos) schimba va trupurile smerite a noastre cum cu asemenea formă să fie către trupul fericat a lui” (25/24 - 26/3), cf. mgh. „A' ki (a’ Christus) által változtattya az mi alázatos testünket, hogy hasonló formáju legyen az ö dicsőséges testéhez”, cf. lat. "Qui (Christus) transfigurabit corpus nostrum humile, ut conforme fiat ejus corpori glorioso”; „Așa cureți cum să luați dobînda” (40/13-14), cf. mgh. „Vgy fussatok hogy a' jutalmat el vehessétek”, cf. lat. "Sic currite, ut comprehendatis”; „Fie voia ta: cum în cer așa aici pre pămînt încă” (40/22-23, 43/6-7), cf. mgh. „Légyen a' te akaratod, miképpen a' menyben azonképpen itt e' földön is”, cf. lat. „Fiat voluntas tua, quemadmodum in cœlo, sic etiam in terra”; „Dăne nouă toate ce mi-s de lipsă pre hrana acestei vieți” (43/21-22), cf. mgh. „Szolgáltass ki minékünk mindeneket, valamellyek ez életnek tápláltatására szükségesek”, cf. lat. „Suppedita nobis omnia, quæ ad hanc vitam sunt necessaria”. De regulă, în aceste cazuri, versiunea latinească este mai concisă decît cea maghiară care oferă mai multe elemente lămuritoare (de ex. sinonime) sau de explicitare și pentru care optează, în cele din urmă, și traducătorul român.

\footnotetext{
${ }^{13}$ De altminteri, segmentul cuprinde și două calcuri după maghiară: unul de expresie: veselitură 'consolare', cf. mgh. vigasztal- 'a veseli' -ás 'suf. -itură’ și unul de semnificat: a via 'a se folosi (de ceva), a profita (de ceva)', 'a întrebuința', cf. mgh. élni 'a trăi, a via', élni valamivel 'a profita (de ceva)'.
} 
Într-un alt caz, formularea românească este concisă ca în textul latin, dar cuprinde un element care trimite (și) la versiunea maghiară, precum în: „înaintea dregătorului de afară” (18/16), cf. mgh. „külső polgári társaságbéli bíró előtt”, cf. lat. „coram judice politico”.

O notă suplimentară față de textul latinesc, introdusă și în versiunea maghiară, întîlnim în: „Iacă Vergură va prinde în sgăul său, și va naște un făt, și-l va chema acela Immanuel aceea e aceea Dumnedzeu cu noi” (12/24-26), cf. mgh. „Ímé egy szüz fogad az ő méhében és szül fiat és nevezed azt Immánuelnek, velönk Istennek”, cf. lat. „Ecce virgo concipier, et pariet filium, et vocabis nomen eius Immanuel” 14 .

În mod asemănător, față de concizia textului latinesc, formularea românească este la fel de detaliată și de explicită ca și în sursa maghiară, în: „Că pre noi din toate păcatele noastre ne slobozește și ne ispăsește” (15/25 - 16/1), cf. mgh. „Mert minket minden büneinkből meg szabadít és üdvözit”, cf. lat. „Quia nos salvat ab omnibus peccatis nostris”; "Oarecine numele lui de-a-fietele îl va pomeni au îl va numi” (34/24), cf. mgh. „a’ ki az ő nevét hijában említi, vagy nevezi”, cf. lat. „qui nomen eius vane usurpaverit”; „De pre rugăciune au rugare” (40/15), cf. mgh. „Az imádságrol, avagy könyörgésröl”, cf. lat. „De Precatione”; „și cum eu încă acelui șirag sunt o parte vie, și fi voi pînă în vecie” (22/16-17), cf. mgh. „és hogy én is annak a' seregnek egygyik élő tagja vagyok, és lészek mind örökké”, cf. lat. „meque vivum huius cœus membrum esse, et mansurum".

O situație interesantă o constituie și prezența determinantului sfînt, regăsit, destul de consecvent în traducerea românească, și care se notează doar în versiunea maghiară, nu și în cea latinească, precum în: "Patru Evangheliomuri: $\boldsymbol{S f i ̈ n t}[\mathrm{ul}]$ Mate[i], $\boldsymbol{S}$ înt [ul] Marc[u], $\boldsymbol{S}$ fint [ul] Luca și $\boldsymbol{S}$ fînt [ul] Ioan” (8/7-10), cf. mgh. „Négy Evangeliomok. $\boldsymbol{S z}$. Mattheé, $\boldsymbol{S z}$. Marké, $\boldsymbol{S} \boldsymbol{z}$. Lukácsé és $\boldsymbol{S z}$. Jánosé”, cf. lat. „Quatuor Evangelia. Matthæi, Marci, Lucæ, Iohannis” ${ }^{15}$; "carele Sfint Paul Apostol din trei Evangeliștii, din $\boldsymbol{S f i n t}$ Matei, Sfint Marc, și din Sfînt Luca așa citește” (29/14-17), cf. mgh. „Szent Pál Apostol a’ három Evangelistákbol, Szent Mathébol, Szent Markbol, és Szent Lukácsbol így olvas”, cf. lat. „Quam Apostolus Paulus ex tribus Evangelistis, Matthæo, Marco, et Luca sic recitat”; „Cărți a lu Sfint Paul Apostol” (8/1314), cf. mgh. „A $\boldsymbol{S} \boldsymbol{z}$. Pal Apostol levelei”, cf. lat. „Epistolæ Pauli Apostoli” etc. Însă, spre deosebire de exemplele anterioare, aceste inserturi nu sînt atît de reprezentative, întrucît ele pot reflecta și o anumită deprindere premergătoare a autorului, eventual o anumită normă de redare a acestor contexte.

\subsubsection{Omisiunile ca mărci ale traducerii}

Față de inserturi, omisiunile observabile în textul lui Fogarasi sînt mai puține la număr și ele reprezintă, de regulă, indicii ale întrebuințării sursei maghiare, întrucît lipsa unor elemente din traducerea românească, respectiv din versiunea maghiară se constată față de prezența acestora în versiunea latinească. Cu alte cuvinte, omiterea din traducerea românească a unui cuvînt sau a unei sintagme care se regăsește în versiunea latinească poate reflecta influența textului maghiar, întrucît acel termen sau acea sintagmă nu apare nici în sursa maghiară. O asemenea situație întîlnim în: „Veniţi toți la mine cari v-aţi ostenit” (10/1-2), cf. mgh. "Jöjjetek én hozzám mindnyájan, akik megfáradtatok”, cf. lat. „Venire ad me omnes, qui fatigati estis et onerati”.

În mod asemănător, versiunea latinească cuprinde segmente care nu se regăsesc nici în versiunea maghiară şi nici în traducerea românească, ceea ce poate constitui un indiciu al întrebuințării sursei maghiare în acea porțiune a textului, precum în: „Ce era neputere Legiei Dumnedzeu trimise Fiul său prentru păcat, cum îndereptăciunea Legiei în noi să se umple” (12/11-13), cf. mgh. „A' mi az Törvénynek lehetetlen vala, az Isten az ő Fiát el bocsátá az bủnért, hogy a Törvénynek amaz jussa, avagy meg igazítása mi bennünk bé tellyesednék”, cf. lat. „Qui legis erat impotentia, Deus suo ipsius Filio misso, pro peccato, condemnavit peccatum in carne, ut jus ilud legis compleatur in nobis".

\footnotetext{
${ }^{14}$ De altfel, formularea aceea e aceea 'adică, cu alte cuvinte' calchiază expresia mgh. $a z a z$ 'id., însă, în acest segment, traducătorul o întrebuințează independent de textul-sursă. Cu numeroase alte ocazii, însă, calcul se înregistrează în același context cu echivalentul său formal unguresc $a z a z$, corespunzînd (și) lat. hoc est.

${ }^{15} \mathrm{Pe}$ de altă parte, fragmentul românesc înregistrează și pronunțarea ungurească a termenului evangheliom (față de evanghelie), respectiv a numelor proprii Luca și Ioan, care, în textul românesc, sunt scrise Lukáts și János.
} 
Atît din punct de vedere semantic, cît și privind concizia, traducerea românească redă segmentul din versiunea maghiară, în: „Care (Isus Hristos) este pus nouă de la Dumnedzeu mîndrie și descumpărăciune” (16/13-14), cf. mgh. „A' ki (a' Jesus Christus) tétetett mi nekünk az Istentöl böltseséggé és váltsággá”, cf. lat. "Qui (Christus Iesus) factus est nobis sapientia a Deo, justitiaque et sanctificatio, et redemptio”.

O situație asemănătoare găsim în: „Căce au păţit Hristos: Supt Pontius Pilatus?” (18/13-14), cf. mgh. "Miért szenvedett a' Christus Pontius Pilatus alatt?”, cf. lat. „Cur Christus sub judice Pontio Pilato passus est?".

La fel, în versiunea latinească, segmentul este mai amplu decît în cea maghiară care omite anumite porțiuni, asemenea traducerii românești, în: „El (Mesia) au răbdat dureri prentru hicleniile noastre” (20/1011), cf. mgh. „Ö (Messias) fájdalommal illettete a’ mi álnokságinkért”, cf. lat. „Ipse (Messias) dolore afficitur a defectionibus nostris, atteritur ab iniquitatibus nostris”.

\section{Concluzii}

Luate în ansamblu, inserturile înregistrate în Catehismul calvinesc din 1648, respectiv omisiunile operate de Fogarasi reflectă o anumită concepție a traducătorului asupra actului traducerii, în general, respectiv asupra funcționalității și a disponibilității celor două surse aflate la îndemîna autorului, în special. În acest sens, se poate spune că, în numeroase cazuri, sursa maghiară se bucură de prioritate, ea devenind predominantă, dacă nu chiar exclusivă, pe anumite porțiuni, faţă de cea latinească care pare să-i fi servit ca una secundară, suplimentară, eventual, de control. De altminteri, o atare ierarhizare a punerii la contribuție a celor două surse se poate susține şi la nivelul macrostructural al întregii traduceri, dovezile oferite de inserturi și omisiuni fiind coroborate cu celelalte mărci ale traducerii, precum împrumuturile culte preluate din textul-sursă maghiar, calcurile după maghiară şi alte construcții mai ample sau mai restrînse care urmăresc tiparul morfo-sintactic maghiar. Predilecția față de sursa maghiară s-ar putea explica, eventual, și prin faptul că limba maghiară îi era mai accesibilă traducătorului decît cea latină pe care putea să nu o fi stăpînit decît în mod superficial.

În ceea ce privește statutul inserturilor și al omisiunilor, acestea se prezintă, în textul lui Fogarasi, cu diverse funcționalități care variază de la caz la caz, dar care pot fi grupate în două clase esențiale, reflectînd două nivele de performanță diferite. Astfel, unele reprezintă soluții preponderent imediate care se înscriu în sfera imitației, ele fiind rezultatul unor constrîngeri impuse de textul-sursă maghiar. Altele pot fi încadrate în sfera creației, ele apărînd în mod independent de ambele surse, în urma unei intervenții individuale a traducătorului. Atît primele, cît și cele din urmă puteau urmări, pe de o parte, inteligibilitatea, traducătorul avînd în vedere, în primul rînd, receptorul căruia i se adresează și, pe de altă parte, îmbogățirea și nuanțarea exprimării, în limitele oferite de nivelul de competențe al emițătorului și al receptorului, dar şi de disponibilităţile limbii române vechi. De asemenea, unele dintre aceste inserturi şi/sau omisiuni reflectă o opțiune deliberată și asumată a autorului, altele ar putea fi atribuite (și) unor „scăpări”, cu alte cuvinte, unor cauze care scapă de controlul conștientului, determinate, eventual, de natura bilingvă a traducătorului.

În mod cert, cauza principală a majorității inserturilor și omisiunilor întîlnite în textul lui Fogarasi o constituie diferențele observabile între cele două surse întrebuințate, maghiară și latină. Însă, ceea ce ni se prezintă interesant este faptul că traducerea lui Fogarasi nu consemnează inserturi care urmăresc exclusiv sursa latinească, ele negăsindu-se în cea maghiară, și nici omisiuni care s-ar datora exclusiv versiunii latine, în sensul că versiunea maghiară ar cuprinde ceva în plus faţă de textele latin și român. În toate cazurile, inserturile și omisiunile sînt fie independente de ambele surse, fie determinate de sursa maghiară.

Constatările care s-au făcut cu privire la cazul particular al textului analizat ar putea fi valorificate și din perspectivă diacronică, urmărindu-se traducerile românești premergătoare și/sau ulterioare ale catehismului de la Heidelberg care au dus la configurarea variantei românești relativ consacrate a acestuia. De asemenea, un real interes ar putea prezenta (și) urmărirea paralelă a catehismului calvinesc din $1648 \mathrm{cu}$ cel din 1656, întrucît cele două traduceri par să fi avut la bază aceeași versiune latino-maghiară a catehismului 
de la Heidelberg. Un asemenea studiu comparativ ne-ar putea furniza mai multe informații cu privire la criteriile care au guvernat opțiunile vechilor traducători ai catehismului în discuție, dar și cu privire la considerentele care au determinat utilizarea, integrală sau parțială, a unui anumit izvor.

\section{Bibliografie}

\section{A. Texte și ediții de texte}

Barițiu, G. (1879). Catechismulu calvinescu impusu clerului și poporului romanescu sub domnia principiloru Georgiu Rákoczy I. și II., transcrisu cu litere latine după edițiunea II tipărită in anulu 1656, insocitu de una escursiune istorica și de unu glosariu de Georgiu Baritiu, Sibiu.

Catechismus Az az; A' kerejztyéni Vallájnak és Hûtnek Rövid kérdésekben és feleletekben foglaltatot fzentirásbeli bizonyfägokval meg erósittetet fummája avagy veleje. Mellyet Deák és magyar nyelvbóI Oláh-nyelvre forditot. Fogarasi Istvan. Lugofi már az iga/ságot rész szerint meg-ifmet Olah Magyar Ecclefíanak lelki Páfztora. [...] Feiervarat Nyomtattatott. Bra/sai Major Márton áltai 1648. Esztendöben // Catechismus / Aceea e aceea; Summa sau Măduva a uluitei și a credinței creștinești, cuprinsă în intrebări, și răspunsuri scurte; și cu adevărături din scriptura svăntă. Catechifmus Latino, Ungarico, Walchicus Translatus opera ac Studio Stephani Fogarafi Symmiftae Oppidi Lugas, Anno 1647 die 18, Decembri [...], în ediția: Tamás, L. (1942). Fogarasi István kátéja. Fejezet a bánsági és hunyadmegyei ruménség müvelödéstörténetéböl, Minerva Irodalmi és Nyomdai Műintézet, Kolozsvár, p. 43-65.

Catechismus Religionis Christianae compendiose propositus, \& sacrarum literarum testimoniis confirmatus. Ex ore infantium et lactentium disposuisti laudem. Psal. 8.3. Matth. 21.16. Albe Jvlie. M. DC: XXXXIII [1643] // Catechismus Az az; A' keresztyeni vallásnak és hütnek rövid kérdésekben és feleletekben foglaltatott, szent irásbéli bizonyságokkal megh erössittetett summája, avagy veleje. A' még szólni nem tudó és csecsszopo gyermecskéknek szájokbol rendelted véghez vinni à te dicseretedet. Psal. 8.3. Matt.21.16. Fejér Váratt. M. DC. XXXXIII. [1643], în ediția princeps din Biblioteca Muzeului Ardelean (Erdélyi Múzeum Könyvtára) [online]. Vezi și edițiile: Catechismus Religionis Christianae... M.DC.XLVII [1647] și Catechismus Religionis Christianae... M.DC.XXXIX [1639].

Gaster, M. (1891). Chrestomatie română. Texte tipărite și manuscrise [sec. XVI-XIX], dialectale și populare, cu o introducere, gramatică și un glosar româno-francez de M. Gaster, vol. I, Introducere, gramatică, texte [1550-1710], Lepizig-Bucuresci.

Hasdeu, B.P. (1879). Cuvente den bătrăni, vol. II, Cărțilepoporane ale Românilor în secolul XVI în legătură cu literatura poporană cea nescrisă, București.

\section{B. Cărți de bibliografie veche}

BRV I = Bianu, I. \& Hodoș, N. (1903). Bibliografia românéscă veche 1508-1830, tomul I, 1508-1716, Edițiunea Academiei Române, Bucuresci, 1903.

$\mathrm{BRU}=$ Veress, A. (1931). Bibliografia română-ungară, volumul I, Românii în literatura ungară și ungurii în literatura română (1473-1780), București, 1931.

Veress, E. (1910). Erdélyi régi oláb könyvek 1544-1711 (10 szövegképpel), în „Erdélyi Múzeum”, an V, 1910, vol. XXVII, p. $142-176$.

RMK I = Szabó, K. (1879). Régi Magyar Könyvtár. Az 1531-1711. megjelent magyar nyomtatványok könyvészeti kézikönyve, M. Tud. Akadémia, Budapest.

RMK II = Szabó, K. (1885). Régi Magyar Könyvtár, vol. II, Az 1473-tól 1711-ig megjelent nem magyar nyelvû hazai nyomtatványok könyvészeti kézikönyve, M. Tud. Akadémia, Budapest.

RMNY III = Heltai, J., Holl, B., Pavercsik, I. \& Vásárhelyi, J. (2000). Régi magyarországi nyomtatványok 1636-1655, vol. III, Akadémiai Kiadó, Budapest.

\section{Lucrări de referință}

Arvinte, V. \& Gafton, Al. (2007). Palia de la Orăştie (1582). II. Studii, Editura Universităţii „Alexandru Ioan Cuza,” Iaşi.

Drăganu, N. (1914). Două manuscripte vechi. Codicele Todorescus și Codicele Marțian, București.

Drăganu, N. (1922). Cea mai veche carte rákóczyană, în „Anuarul Institutului de Istorie Naţională”, I, 1921-1922, Cluj, Institutul de Arte Grafice „Ardealul”.

Gheție, Ion. (1975). Baza dialectală a limbii române literare, Editura Academiei Republicii Socialiste România, București.

Iorga, N. (1904). Istoria literaturii religioase a românilor pînă la 1688, București.

Iorga, N. (1928). Istoria Bisericii românești și a vieții religioase a românilor, ed. a II-a, revăzută și adăugită, vol. I, Editura Ministeriului de Culte, București.

Juhász, I. (1940). A reformáció az erdélyi románok között, Kolozsvár.

Marienescu, M. (1902). Luteranismul, calvinismul și introducerea limbii române în bisericile din Ardeal, în „Analele Academiei Române", seria II, tom. XXIV, Memoriile Secțiunii Istorice, București, p. 165-190.

Nădejde, I. (1886). Introducere în istoria limbii și literaturii române, Iaşi.

Niculescu, Al. (2006-2007). Tatăl nostru, în „Dacoromania”, serie nouă, XI-XII, p. 17-75, Cluj-Napoca. 
Pantaleoni, D. (2007). Observații asupra textelor româneşti vechi cu alfabet latin (1570-1703), în „Philologica Jassyensia”, an III, nr. 1, p. 39-56.

Philippide, A. (1888). Introducere în Istoria limbei și Literaturei romîne, Iași.

Sbiera, I. G. (1897). Mişcări culturale și literare la românii din stânga Dunării în răstimpul de la 1504-1714, Cernăuți. 